\title{
Response of Rice Crop to Convenential and Mechanical Cultivation Methods under $\mathrm{N}$ - fertilization Levels
}

\author{
Radwan, F. I ., M. A. Gomaa, I. F. Rehab and Hala, M. S. H. Mahmoud \\ plant production Dep. Faculty of Agriculture (Saba Basha) Alexandria University, Egypt
}

\begin{abstract}
Two field experiments were carried out at the Experimental Farm of the Faculty of Agriculture (Saba Basha), Alexandria University, at Abees region, Alexandria. Egypt during the two successive seasons of 2012 and 2013 to study the response of rice crop to convenential and mechanical cultivation methods under $\mathrm{N}$ - fertilization levels on the yield, its components and technological characters of sakha 101 variety.

The experiment design was a split plot with three replicates. The main plots were occupied by nitrogen levels (40,60 and $80 \mathrm{~kg} \mathrm{~N} / \mathrm{fed}$ ), while the subplots were consisted of two planting methods (manual transplanting and mechanical transplanting).The main results could be summarized as follows: Increasing nitrogen levels up to $80 \mathrm{~kg} \mathrm{~N} / \mathrm{fed}$, significantly decreased plant height and significantly increased yield and its components and rice grain quality characters in the two planting methods while, these increases were higher in manual transplanting than mechanical transplanting in the two seasons. on the other hand, the rice production in manual transplanting per fed, increased by $41.80 \%$ comparing with mechanical transplanting.
\end{abstract}

Key words: Manual transplanting, Mechamcal transplanting, nitrogen level rice crop.

\section{INTRODUCTION}

Rice (Oryza sativa, L.) is one of the most important and leading food crops of the world and now is the major stable food of over half of the world population. More important, it is the stable food in area of high population density and fast population growth. The green revolution has enabled rice production to meet the demand of the growing population and most of the increased demand will be in developing countries.

The demand for food grains in Egypt had been increased and will continue to increase with the increase in population and the rice in the standed of living. Rice cultivated are ranges from 0.50 to 0.60 million hectare (1.2 to 1.5 million fed). The average of rice productivity in 2007 season was 10.0 t/ha (4.2 $\mathrm{t} / \mathrm{fed}$ ) and total rice production was 6.0 million through increasing yield per unit area has been accomplished by some combined effects such as nitrogen fertilization and transplanting methods.

Increasing nitrogen efficiency through the most important factors that limit productivity of rice (Salem et al., 2005). Also, rice cultivars may differ in their requirements of nitrogen levels to produce the maximum grain yield and the highest technological properties of rice grains (Ebaid and Ghanem, 2000).

Planting methods play an important role in rice production. Transplanting rice manually is a higher demanding operation equaling intensive labour for few days in a season (El- Kasaby et at., 2002). Also, Abdou (1995) reported that the manual transplanting gave a rice production more than the mechanical transplanting. Also, Aref (1990) carried out comparative studies of different mechanization methods on rice production. This investigation aimed to study 
the effect on productivity of rice convenential and mechanical cultivation methods under $\mathrm{N}$ - fertilization levels.

\section{MATERIALS AND METHODS}

To achieve the aim of the present work, two field experiments were carried out at the Experimental Farm, Faculty of Agriculture (Saba- Basha), Alexandria University, Egypt, during 2012 and 2013 seasons. The experiments were carried out to study the effect on the productivity of rice variety sakha 101 convenential and mechanical cultivation methods under $\mathrm{N}$ - fertilization levels.

A split plot design with three replications was used, the main plots were occupied by nitrogen levels $(40,60$ and $80 \mathrm{~kg} \mathrm{~N} / \mathrm{fed}$ ), while the subplots were consisted of two planting methods (manual transplanting and mechanical transplanting).

\section{1- Manual transplanting}

The nursery area was well prepared and rice seeds at a rate of 40 $\mathrm{kg} / \mathrm{feddan}$ were socked for 24 hours and incubated for 24 hours, then the seeds were handily broadcasted. Twenty five days old seedlings were transplanted at the rate of 4 seedling/hill adopting a spaces of $15 \times 15 \mathrm{~cm}$.

\section{2- Mechnaical transplanting}

For transplanting rice, it is necessary to prepare the seedling, the paddy field and then transplanted the paddy field with rice seedling.

Preparation of seedling

To use the rice transplanting, it is necessary to get a health seedling through the nursery box.

\section{Nursery box}

It is fabricated from plastic, the inside dimensions of the nursery box are $58 \mathrm{~cm}$ length, $28 \mathrm{~cm}$ width and $3 \mathrm{~cm}$ depth.

Seedling the nursery box

For seedling the nursery box, the same stage as recommended by (rice Mechanization Center, Meet El- Deba, Agric. Research. Institute) and a Japanese textbook of farm machinery on the application of rice mechanical transplanting.

Paddy field preparetion

The field was plowed by using Behira Rau 7 Shares chisel plow, the plowing depth was $12 \mathrm{~cm}$ according to the recommendation of Abdel- Maksoud et al. (1994). The water was floated to an average depth of $3 \mathrm{~cm}$, and the soil was compact about 24 hours after careful padding of its surface.

Seedling

For using the rice transplanting, the following conditions have been taken in this experiment. The height around $25 \mathrm{~cm}$ length of root within $50 \mathrm{~mm}$, tiller within 2 as recommended by Ebaid et al. (2001).

Transplanting mechanism for mat seedling

The machine plants seedlings one by one by using separating time. Transferring the fixed quantity of the seedling on the platform traversely to right and left. When one cycle in finished and the mat seedling reaches the edge of the platform the seedling is sent out below by a longitudinal transferring mechanism and the plant form begins to save again.

The seedling- scparting and planting mechanism makes an approximate elliptic motion at the extremity vis crank action by four links as shown in Fig (1). 
The stubbles are divided by times in order to plant the seedling. The tines press the seedling into the soil, by Yammer diesel engine instruction book, Agricultural machinery.

\section{3- Nitrogen fertilization}

Three nitrogen levels $(40,60$ and $80 \mathrm{~kg} \mathrm{~N} / \mathrm{fed})$ as urea form $(46 \% \mathrm{~N})$ were applied $2 / 3$ basal and corporate in to the dry soil before flooding and $1 / 3$ at panicle initiation.

Soil analysis

Soil samples were collected from $0-30 \mathrm{~cm}$ depth from the experimental sites and the analysis is shown in Table (1) according to the method reported by Page et al. (1982). Other cultural practices were deas recommended in rice fields.

Table (1): Some physical and chemical properties of the experimental soil in 2012 and 2013 seasons

\begin{tabular}{|c|c|c|}
\hline \multirow{2}{*}{ Soil properties } & \multicolumn{2}{|c|}{ Values } \\
\hline & 2012 & 2013 \\
\hline \multicolumn{3}{|l|}{ A-Particle size distribution \% } \\
\hline Sand & 14.30 & 14.20 \\
\hline Silt & 42.00 & 42.70 \\
\hline Clay & 43.40 & 43.10 \\
\hline Soil texture & Clay loam & Clay loam \\
\hline \multicolumn{3}{|l|}{ B- Chemical properties } \\
\hline $\mathrm{pH}(1: 1)$ & 7.80 & 7.70 \\
\hline $\begin{array}{l}\text { EC (1:1), } \\
\text { 1- Soluble cations (1:2) (cmol/kg soil) }\end{array}$ & 3.40 & 3.50 \\
\hline $\mathrm{K}^{+}$ & 1.37 & 1.41 \\
\hline $\mathrm{Ca}^{++}$ & 14.20 & 15.30 \\
\hline $\mathrm{Mg}^{++}$ & 11.40 & 11.30 \\
\hline \multirow{2}{*}{\multicolumn{3}{|c|}{ 2- Soluble anions (1:2) (cmol/kg soil) }} \\
\hline & & \\
\hline $\mathrm{CO}_{3}^{-}+\mathrm{HCO}_{3}^{-}$ & 2.80 & 2.90 \\
\hline $\mathrm{CL}$ & 19.60 & 20.10 \\
\hline $\mathrm{SO}_{4}^{-}$ & 12.30 & 12.50 \\
\hline Calcium carbonate $\%$ & 6.70 & 6.90 \\
\hline Total nitrogen \% & 0.85 & 0.87 \\
\hline Available P (mg/kg) & 3.80 & 3.70 \\
\hline Organic matter \% & 1.50 & 1.45 \\
\hline
\end{tabular}

Data recorded:

At harvest, plants of one square meter were taken from each plot and the following characters were recorded: Plant height, Panicle length, number of tillers $/ \mathrm{m}^{2}$, number of panicles $/ \mathrm{m}^{2}$, number of grains/panicle, number of filled grains/panicle, 1000- grain weight, grain and straw yield/fed and biological yield Guraded $\mathrm{cm}$ square meter of plants were the harvested manually and left three 


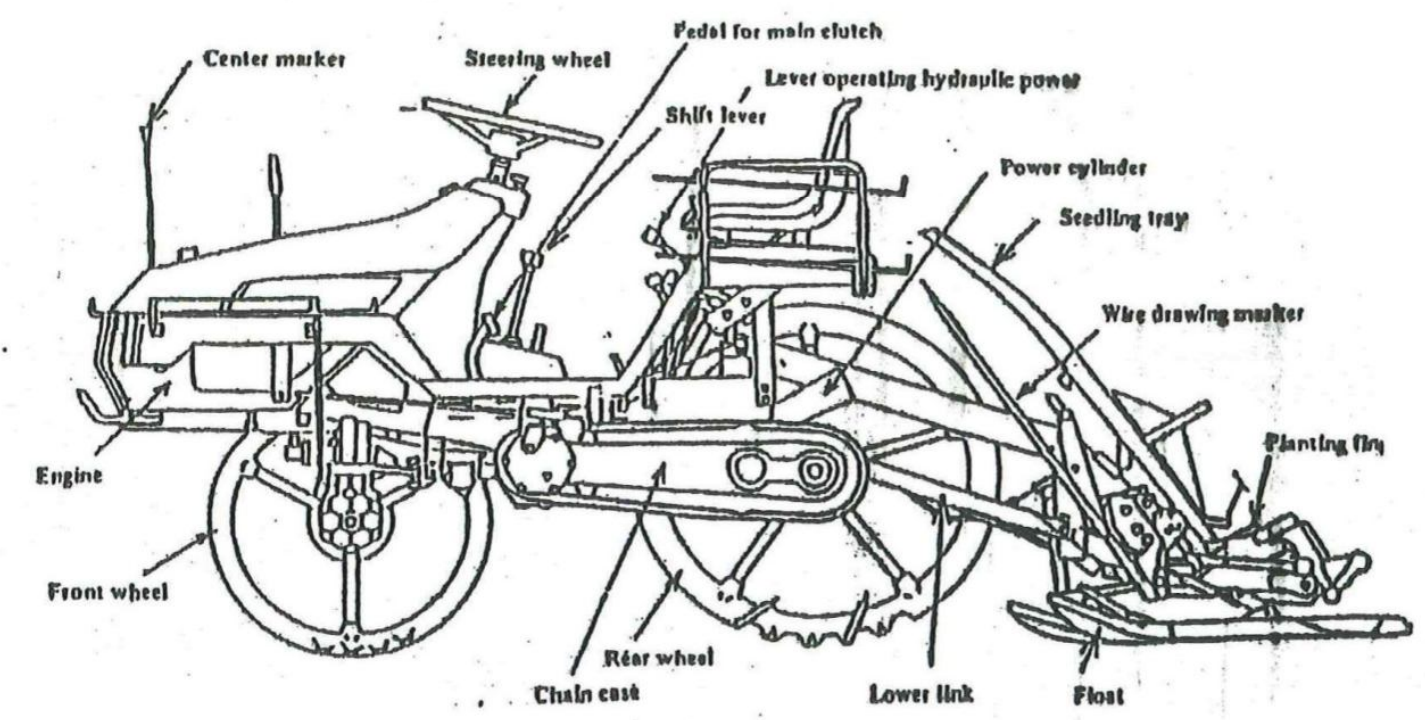

Fig. (1) : Rice transplanter

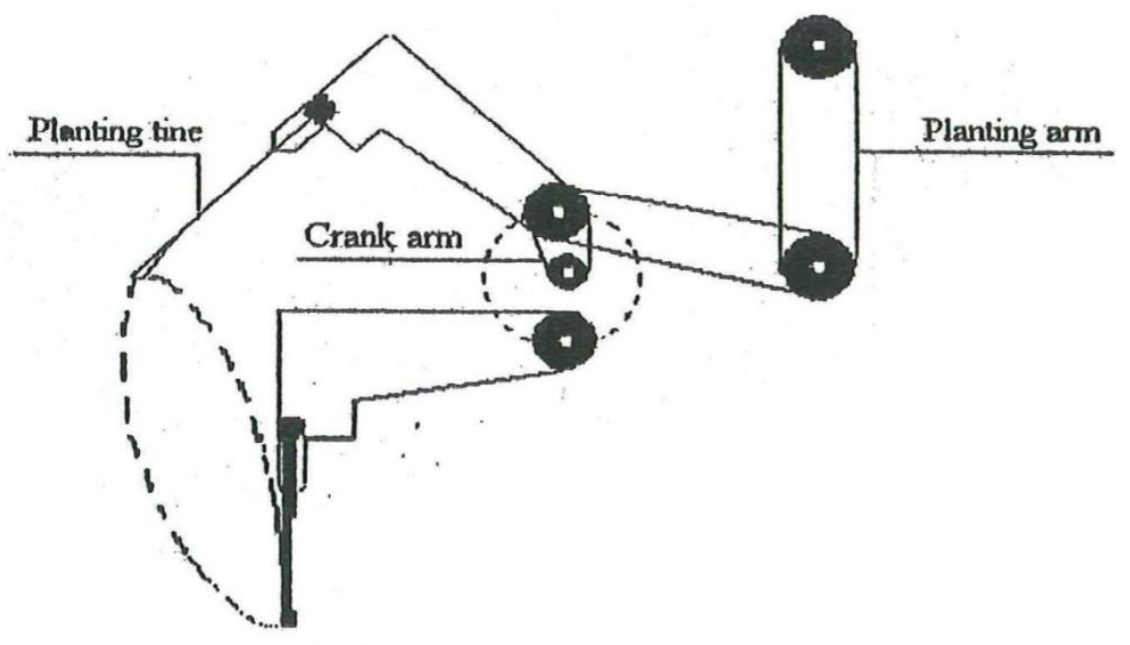

Fig. (2): Transplanting mechanisin: 
days for drying and biomass weight was taken, then mechanically threshed and grain yield was estimated and adjusted to $14 \%$ moisture content.

Technological characters of grains

Grains samples $(250 \mathrm{gm})$ from each sub- plot was taken to determine some technological characters (Hullig \%, Milling\% and broken rice \%). These technology tests were carried out at Rice Technology Trainining Center (RTTC), Alexandria.

All data collected were subjected to statistical analysis of variance according to Gomez and Gomez (1984). The treatments average were compared using L.S.D test at 0.05 level of significant.

\section{RESULTS AND DISCUSSION}

\section{A- Yield and its components:}

Data in Tables (2 \&3) showed that increasing nitrogen levels up to $80 \mathrm{~kg}$ $\mathrm{N} / \mathrm{fed}$, significantly increased all yield and its components except plant height was decreased by increasing nitrogen levels, this decrease due to nitrogen application delay leaves aging and increased root activity during grain filling and increase grain fertility which greatly increase grain yield. These results are in similar with Abdel- Rahman et al. (1990), Hassan et al. (1990) and Ebaid et al. (2001). This increase may be due to that increasing nitrogen supply minimized the inter and intra- specific competing, then increased the amounts of metabolites synthesized by rice plants.

The evaluated planting methods exerted highly significant effects on all yield and its components except 1000- grain weight in both seasons Tables (2 \&3). Manual transplanting produced the highest plant height (89.96 \& 93.00 $\mathrm{cm})$, panicle length $(21.22 \& 22.12 \mathrm{~cm})$, number of tillers $/ \mathrm{m}^{2}(519.67 \& 633.78)$, number of panicles $/ \mathrm{m}^{2}$ (513.89 \& 627.22), No. of grains/panicle (1352.56), No. of filled grains/panicle (130.45), grain yield (3.92 \& $5.24 \mathrm{t} / \mathrm{fed})$, straw yield $(7.12$ \& $10.25 \mathrm{t} / \mathrm{fed}$ ) and biological yield (10.82 \& $15.27 \mathrm{t} / \mathrm{fed})$ than mechanical transplanting. These data are in agreement with those reported by Abdou (1995), Ebaid et al. (2001).

The interaction between nitrogen fertilizer and planting methods were significant for yield and its components in both seasons.

\section{B- Technological characters:}

Data in Table (4) indicated the effect of nitrogen levels and planting methods on hulling $\%$, milling $\%$ and broken rice $\%$. Increasing nitrogen level up to $80 \mathrm{~kg} \mathrm{~N} / \mathrm{fed}$, significantly increased the technological grain characters (hulling \% and milling \%) in both seasons, as well as up to $60 \mathrm{~kg} \mathrm{~N} / \mathrm{fed}$, significant increase for broken rice \% in both seasons. These results are in agreement with (Ebaid, 1995 and Ebaid et al., 2001). They reported that increasing nitrogen fertilizer significantly increased the technological characters in rice plants grains.

Manual transplant significantly increased these technological characters (hulling\%, milling\% and broken rice\%) compared with the mechanical transplanting in both seasons. 


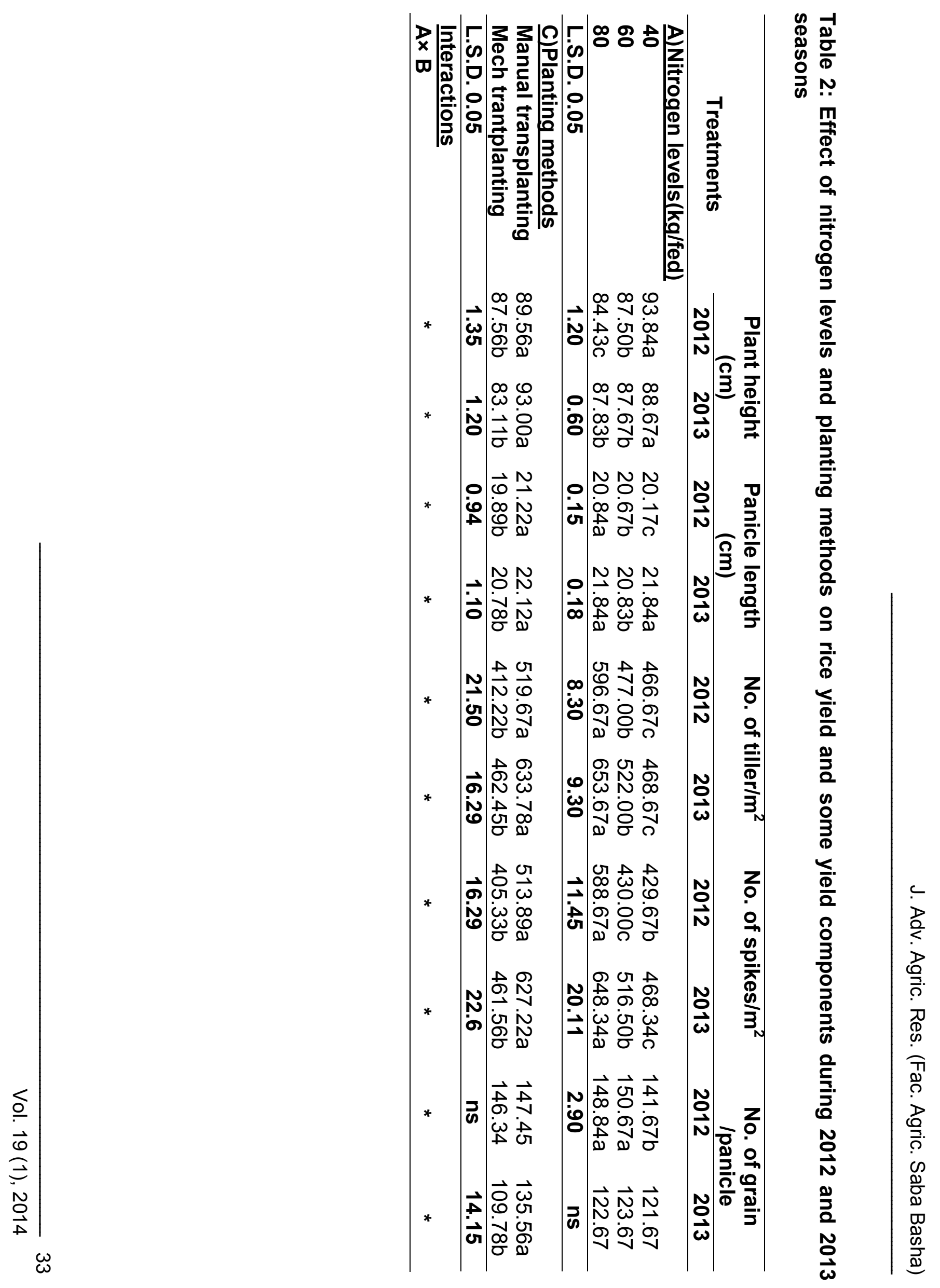




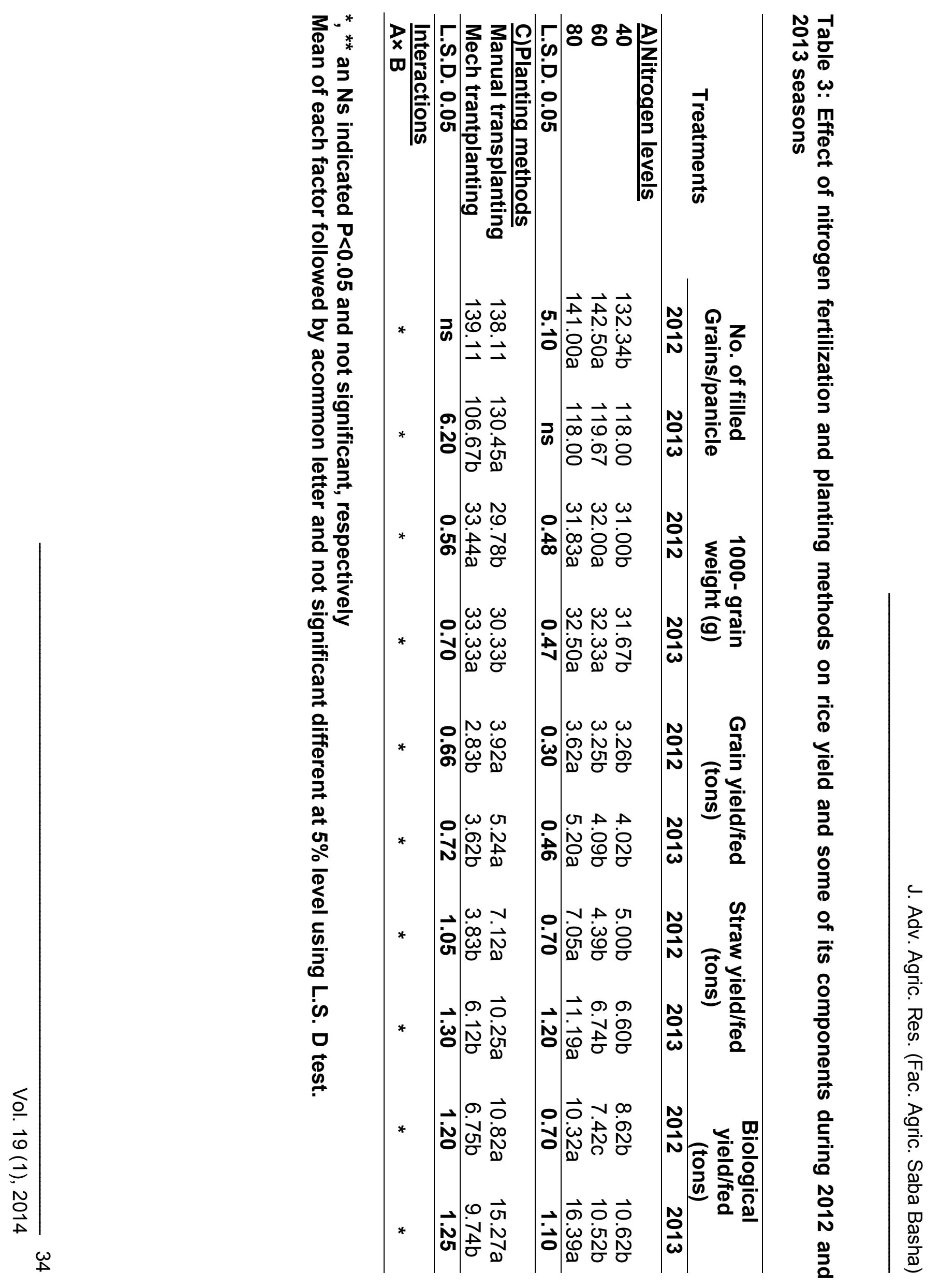




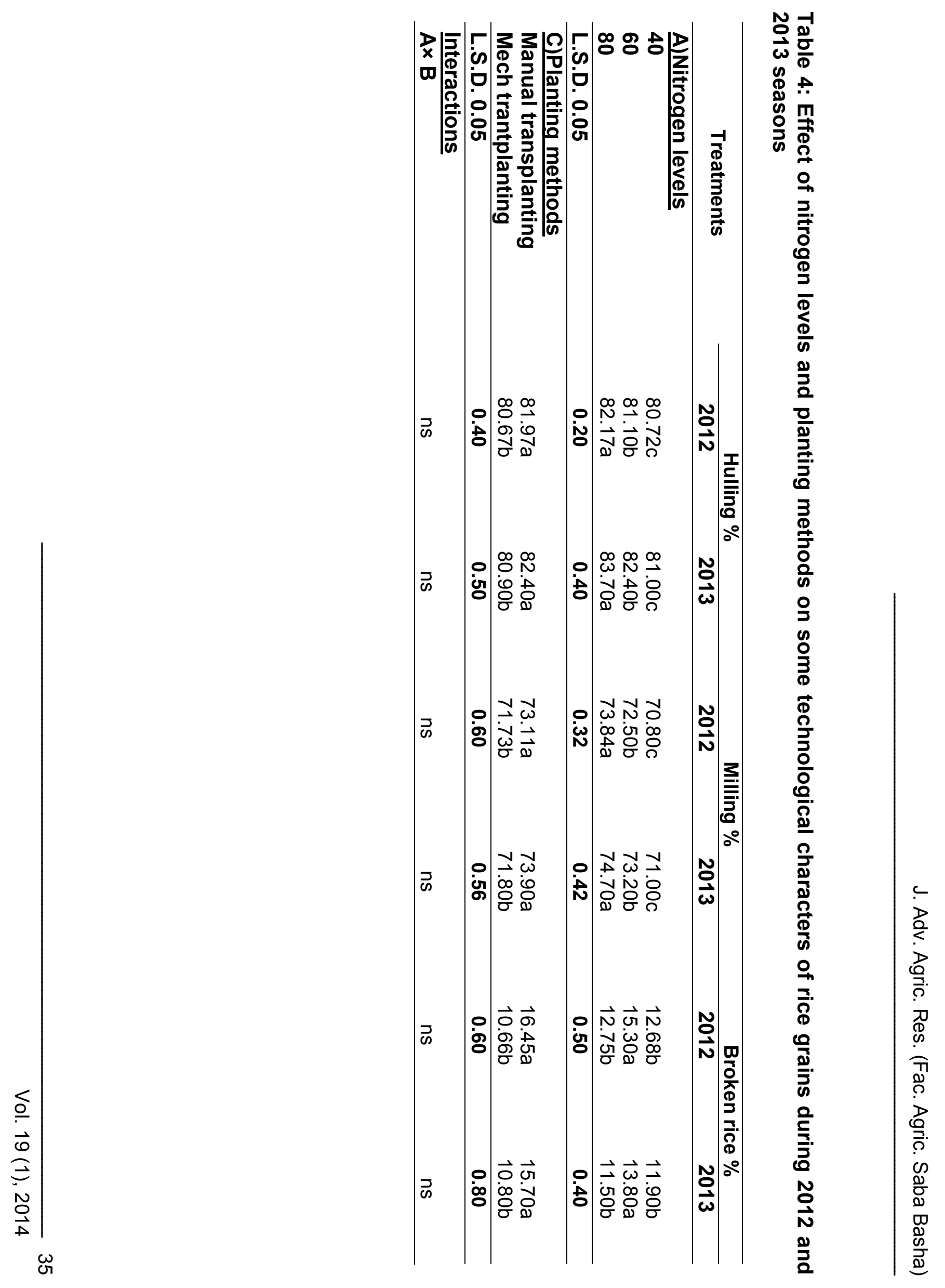


The interactions between nitrogen levels and planting methods were significant for technological characters (hulling \% milling \% and broken rice \%) in both seasons (Table 4).

\section{C-Economic study}

Table (5) indicates the components of mechanical and manual transplanting cost. The rice production cost per feddan in manual transplanting increases by $47.5 \%$ comparing with the mechanical transplanting (Ebaid et al., 2001).

Table 5: Economic study on mechanical and manual rice transplanting methods

\begin{tabular}{lcc}
\hline \multicolumn{1}{c}{ Variables } & $\begin{array}{c}\text { Cost of mechanical } \\
\text { transplanting } \\
\text { L E/feddan }\end{array}$ & $\begin{array}{c}\text { Cost of manual } \\
\text { transplanting } \\
\text { L E/feddan }\end{array}$ \\
\hline grains nursery preparation and & 800 & 1050 \\
transplanting & 120 & 120 \\
Permanent field preparation & 594 & 594 \\
Nitrogen fertilizer & 60 & 60 \\
Herbicides & 250 & 250 \\
Hand hoeing & 340 & 1120 \\
Harvesting & $\mathbf{2 1 6 4}$ & $\mathbf{3 1 9 4}$ \\
\hline Total & & \\
\hline
\end{tabular}

\section{REFERENCES}

Abdel- Maksoud, S. A., M. A. Hassan, M. A. El- Shazly and H. El- Zemeity. 1994. Improving the rice transplanting performance under Egyptian conditions. Misr J. of Agric. Eng. Vol. 11 (3): 805- 817.

Abdel- Rahman, A. A., A. A. Ghanem and A. E. Abdel- Wahab 1990. Productivity of rice as affected by different number of seedlings per hill and nitrogen levels under saline soil. Proc. $4^{\text {th }}$ Conf. Agron. Cairo, Egypt 15- 16 Sept. Vol. 1: 295- 302.

Abdou, F. M. 1995. Development of rice and wheat transplanter at $15 \mathrm{~cm}$ instead of $30 \mathrm{~cm}$ row spacing. Misr J. of Agric. Eng. Vol. 12 (4): 799811.

Aref, A. O. M. 1990. Comparative studies of different mechanization methods on rice production M. Sc. Thesis, Fac. of Agric. Alex. Univ.

Ebaid, R. A. 1995. Studies on the effect of some agricultural treatments on rice productivity Ph. D. thesis, Fac. of Agric. Kafr El- Sheikh, Tanta Univ.

Ebaid, R. A. and S. A. Ghanem 2000. Productivity of Giza 177 rice variety growth after different winter crops and fertilized with different nitrogen levels. Egypt. J. Agric. Res. 78 (2): 717- 731.

Ebaid, R. A., G. H. El- Sayed, A. A. I. Mohamed and Kh. A. A. Khadr 2001. Comparison study between mechanical and manual rice transplanting methods under different nitrogen fertilization levels and weed control. Misr, J. of Agric. Eng. Vol 18 N (3): 769- 780.

El- Kasaby, A. T., A. A. Leilah, A. A. M. Abdel- Rahman and A. M. M. ElEkhtyar 2002. Evaluation of some planting and harvesting methods of rice Egypt J. Agric. Res. 80 (2): 727- 736. 
Gomez, K. A. and A. A. Gomez. 1984. Statistical procedures for agricultural research 2nd . John Wiley \& Sons. Inc., New York.

Hassan, S. M., A. A. Abdel- Rahman and A. T. Badawi 1990. Optimum cultival practices for weed control in broadcast seeded rice. Proc. $8^{\text {th }}$ Conf. Agron. Cairo Egypt., 15- 16 Wept. Vol. (110: 491- 507.

Page, A. L., R. H. Miller and D. R. Keeney. 1982. Methods of soil ananlysis Part.2: chemical and microbiological properties $2^{\text {nd }}$ Ed. ASSA. Midison Wise U.S.A.

Salem, A. K. M., B. A. Zayed, A. G. Ahmed and A. A. Abou- Khalifa 2005. Effect of nitrogen, potash levels and transplanting regularity on rice crop productivity. Egypt. J. Agric. Res. 83 (5B): 447- 454.

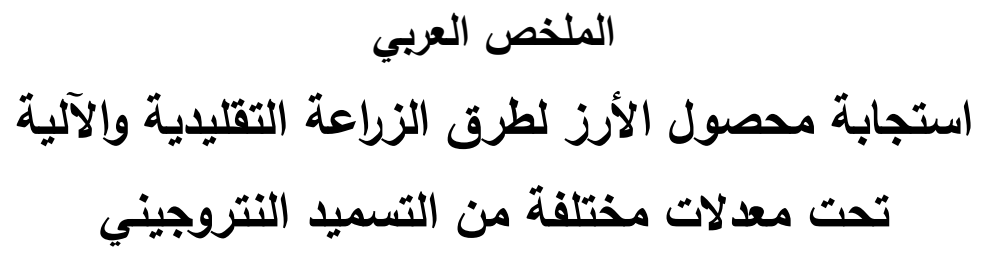

فتحي إبراهيم رضوان، محمود عبد العزيز جمعة، إبراهيم فتح الله رحابو هالة محمد شوقي حسن محمود قسم الإنتاج النباتي ـ كلية الزراعة سابا باشا ـ جامعة الإسكندرية ـ مصر

أقيمت تجربتان حقليتان في مزرعة كلية الزراعة سابا باشا ـ جامعة الإسكندرية ـ بمنطقة أبيس - إسكندرية

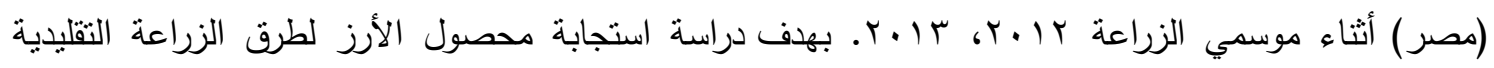

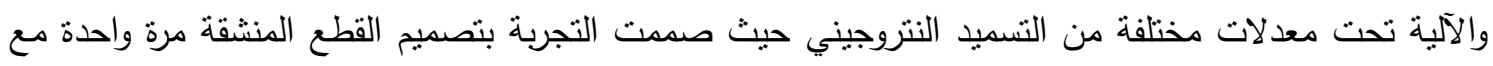
استخدام ثلاث مكررات.

وكاتت التوصبة كما بلي:

- قد أوضحت النتائج أن زيادة التسميد النتروجيني حتى • ـكجم نتروجين/فدان أدى إلى نقص معنوي في طول النبات واءلى زيادة معنوية في المحصول ومكوناته وكذلك الصفات التكنولوجية للحبوب وذللك في كلا لتاني طريقتي الزراعة التقليدية والزراعة الآلية. - من ناحية أخرى أدى استخدام الزراعة النقليدية إلى زيادة صفات المحصول ومكوناته والصفات التهات

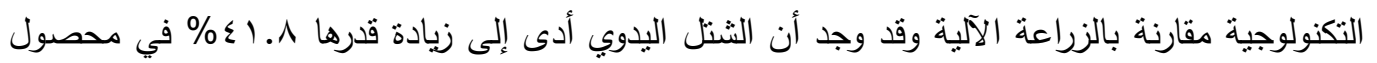
الحبوب مقارنة بالثتل الميكانيكي. 